canadensis seems to have fortunately been passed over without being standardized into conformity with the last catalogue.

In the following list of works consulted, the asterisk indicates use of the valid prior name (canadensis Latreille 1810) instead of its synonym (bicolor Newman 1837).

*1810 Latreille, Consid. General.-Crust. Arach. Ins. Paris, p. 212,430 .

*1825 Lepeletier \& Serville, Encyl. meth., Ins., vol. 10, p. 169, 261.

1837 Newman, Ent. Mag., vol. 5, p. 375.

*1853 Melsheimer, Cat. Coleop. U. S., p. 148.

*1855 LeConte, Proc. Acad. Nat. Sci. Phila., vol. 7, p. 275.

1859 Lacordaire, Gen. Coleop., vol. 5, p. 603, footnote 3.

*1866 LeConte, List Coleop. N. A., p. 64.

1870 Gemmiger \& Harold, Cat. Coleop., p. 2104.

*1874 Crotch, Check List Coleop. Am. N. of Mex., p. 109.

*1885 Henshaw, List Coleop. Am. N. of Mex., p. 129.

1914 Blair, Ann. Mag. Nat. Hist., Ser. 8, vol. 13, p. 313. 1920 Leng, Cat. Coleop. Am. N. of Mex., p. 161.

1928 Blair, Coleop, Cat., Junk, pt. 99, Pyrochroidæ, p. 2. *1931 Payne, Ent. News, vol. 42, p. 13-15.

\title{
A WIREWORM DOUBLE MONSTER (LIMONIUS CANUS LEC., ELATERID AE, COLEOPTERA)
}

By CHAS. E. WoODWoRTH

Associate Entomologist, Division of Truck Crop Insects, U. S. Bureau of Entomology

Quite recently it was my good fortune to find and preserve an interesting monstrosity among some newly hatched wireworm larvæ. In the course of examining about eighteen thousand of these, only one abnormal individual was noted. Besides the great scarcity of anomalies in this group the fact that wireworms are of subterranean 


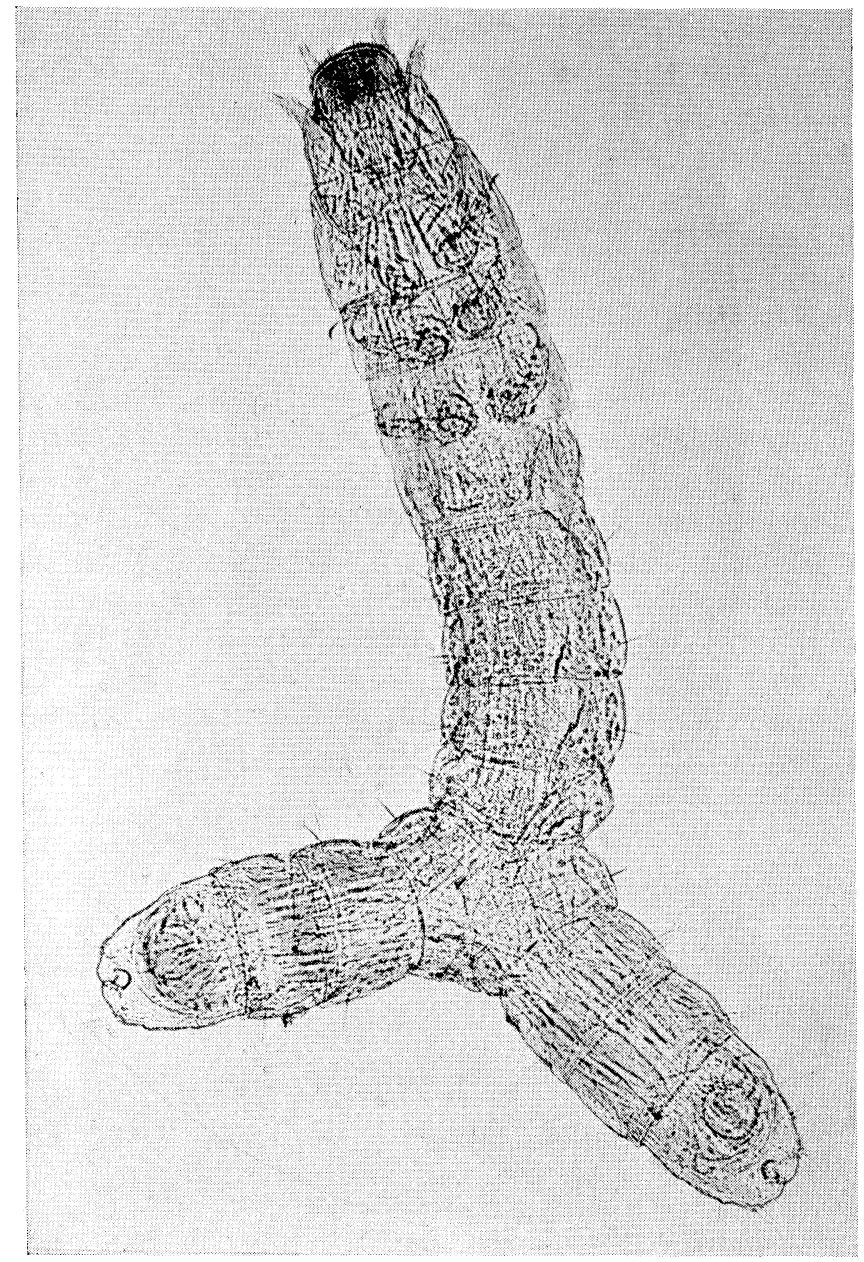

Fig. 1. Partial twin, first instar larval wireworm. Limonius canus Lec., ventral aspect, actual length $2 \mathrm{~mm}$. Enlarged 60 diameters. 
habits makes observation rare indeed. For these reasons it was decided to report this case. In order to insure that this partial twin should not be lost it was killed and fixed as soon as discovered and, as a consequence, growth records were not obtained. It is hoped that another individual will be found so that developmental changes can be noted.

The specific type of anomaly possessed by the individual here reported is classified by Cappe de Baillon ${ }^{2}$ as a symmetrical double monster with lateral abdominal doubling. This particular diplopagisity, according to Wilder ${ }^{3}$, is believed to be due to wide separation of some of the segmentation nuclei in early embryonic development, perhaps being traceable to the two-cell stage. Had there been complete wide separation there would have been identical twins. In phasmid larvæ Cappe de Baillon found that abdominal doubling was very rare as compared to cephalic or thoracic doubling. In fact very few larval irregularities of any type have been reported. In adults abdominal monstrosities are very rare as compared with other types. This fact is strikingly noticed when the literature of reported cases is reviewed.

This particular larva has a perfectly formed head and thorax as well as the first five abdominal segments as far as external study indicates. The sixth segment is irregular in shape, being double at the bottom but single at the top. The last three segments are apparently normal but duplicated. The digestive tract appears to be double throughout the sixth segment and divides at the junction of the fifth and sixth segments, the irregularity beginning about the middle of the fifth. The fat bodies, the only other internal structures visible, seem to conform to the external arrangement. The length of the larva is the same as the rest of the worms from the same mating if either of the tails are used. The volume would be the same if the duplicated parts were removed and the sixth segment trimmed to normal shape. There does not seem to be any atrophy or hypertrophy except as noted above and each duplicated segment is like the corresponding somite of the other half 
and of other larvæ from the same mating except the abdominal segment 6 .

In 1927 Cappe de Baillon wrote a very excellent book which concerned itself entirely with teratology or monstrosities found in insects. While the principle part of the work deals with a study of Carausius morosus Brunner, a phasmid, one that is very prone to irregular development, there is included a 382-title bibliography. Practically all of these references refer to adult irregularities, probably because those forms are the ones found in collections. Most of these malformations take place in the pupal reorganization. How much larger the list would be if larval anomalies such as the one here reported were more often found! In this whole list of references only one deals with elaterids. That one is by Bastine ${ }^{1}$ and concerns itself with an antennal irregularity in an adult of Melanotus rufipes Herbst in which the second antennal article had two extra growths upon it.

\section{Literature Cited}

${ }^{1}$ Bastine, F.

1910 Cas de Monstruosite chez un Elateridæ du genre Melanotus Escholtz. Feuille des Jeun. Nat. $40: 147$.

${ }^{2}$ Cappe de Baillon, $\mathrm{P}$.

1927 Recherches sur la Tératologie des Insectes. Paris, 291 pages, fig. 85, pl. 9, ref. 382.

${ }^{3}$ Wilder, H. W.

1904 Duplicate Twins and Double Monsters. Amer. Jour. Anat. 3: 387-493, fig. 11, pl. 2, ref. 151. 

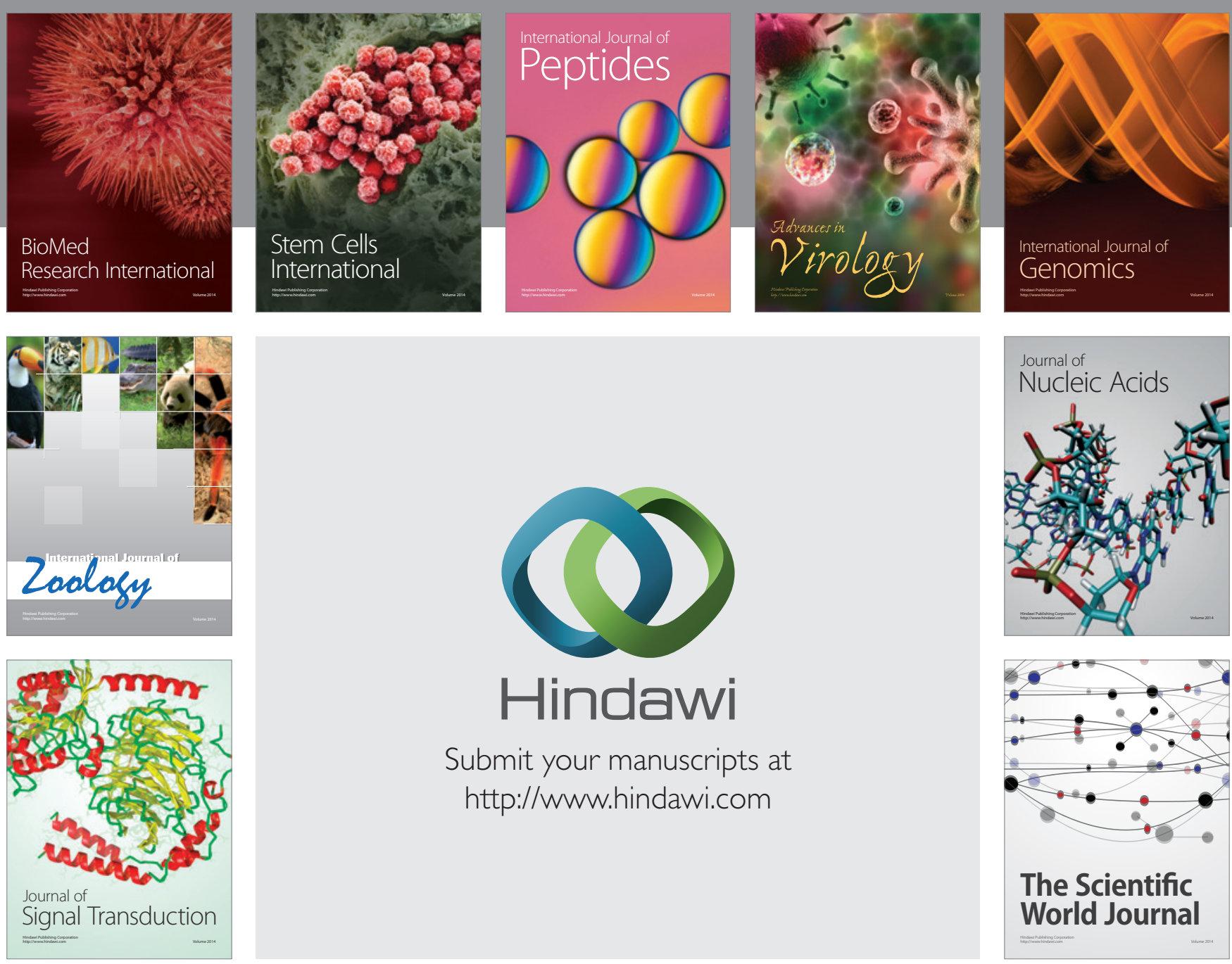

Submit your manuscripts at

http://www.hindawi.com
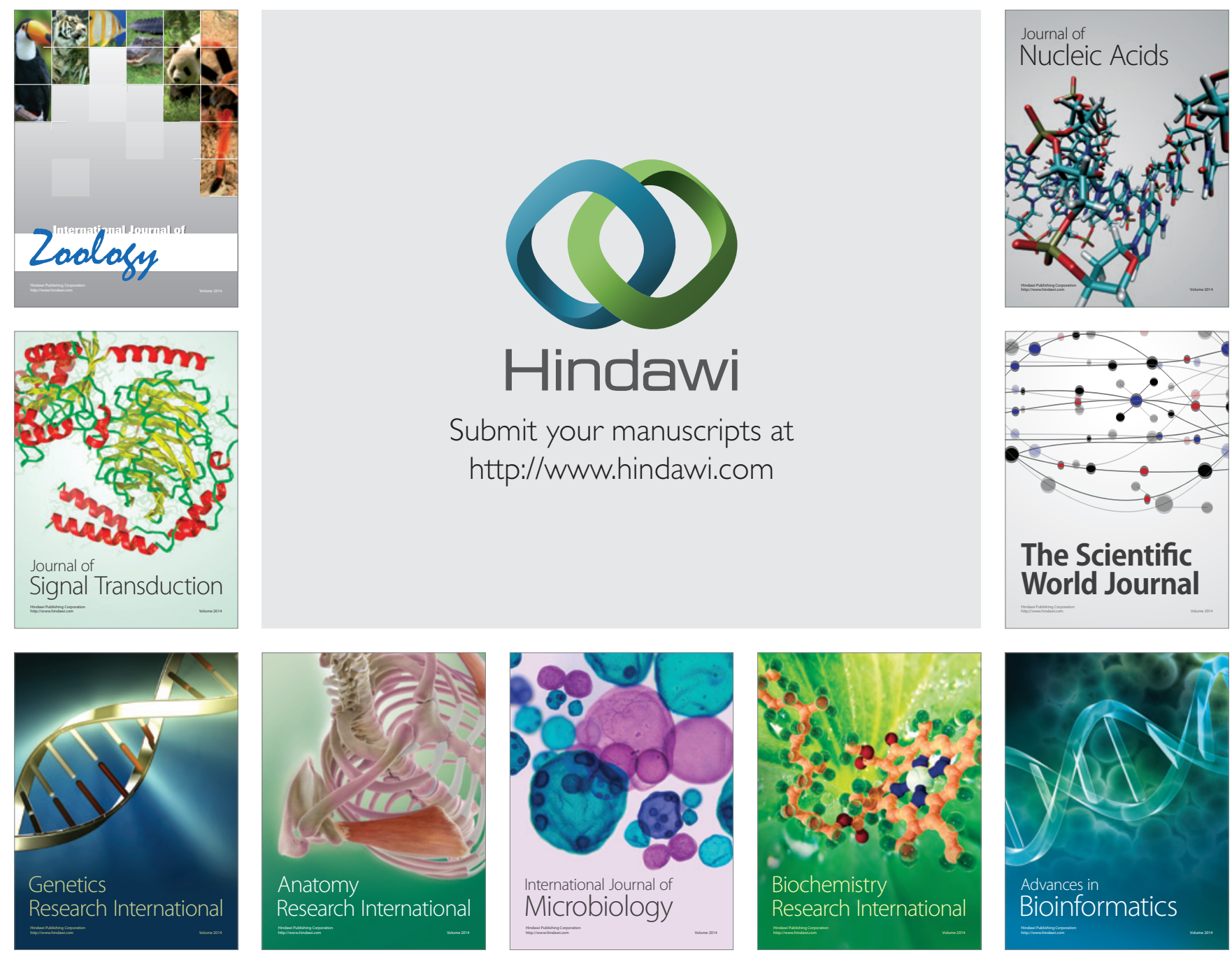

The Scientific World Journal
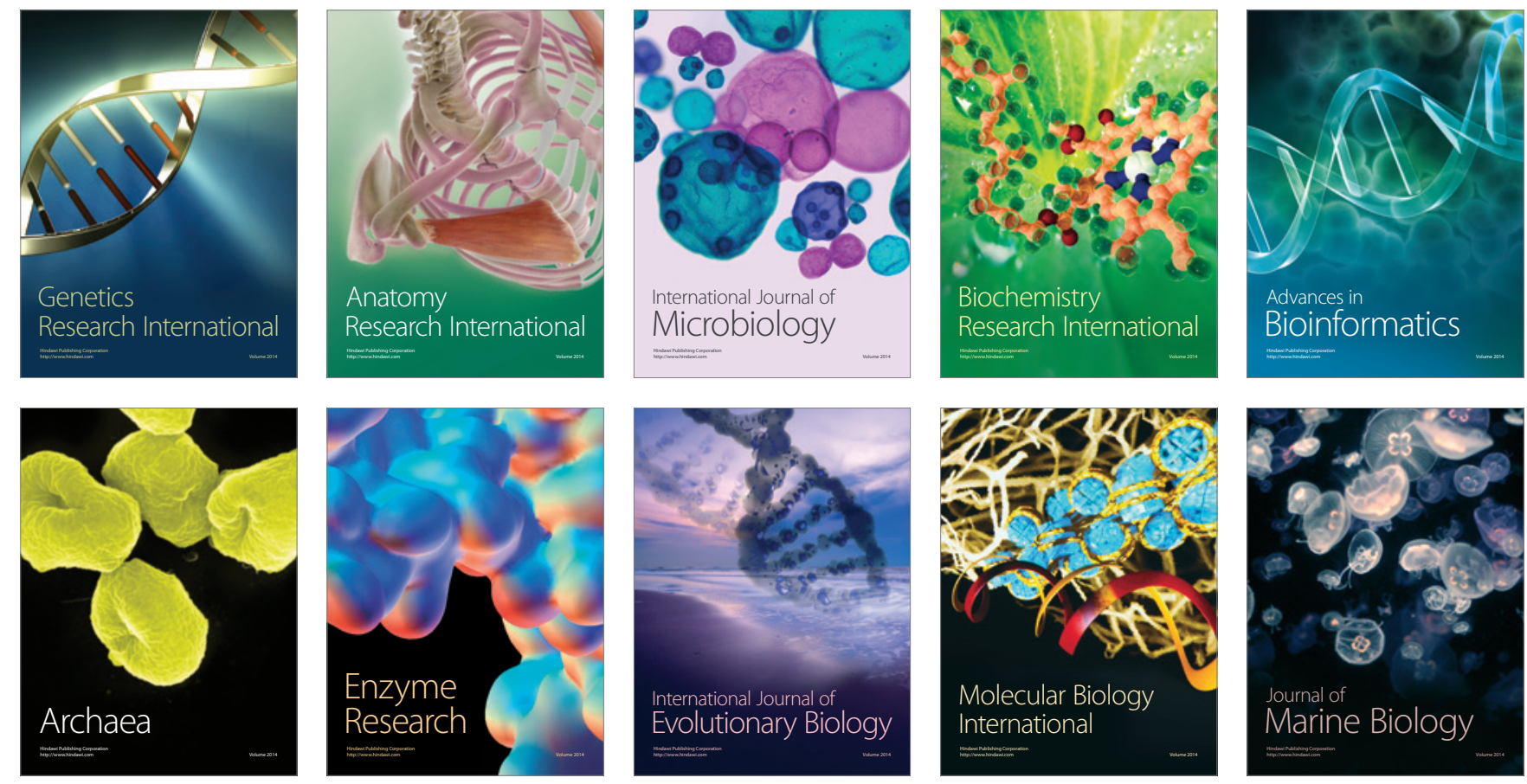